\title{
First detection of species of the potentially toxic genus Azadinium (Amphidomataceae, Dinophyceae) in tropical coastal waters of Brazil
}

\author{
Kaoli Pereira Cavalcante ${ }^{1} \cdot$ Sylvia Maria Moreira Susini-Ribeiro ${ }^{1} \cdot$ Urban Tillmann $^{2}$
}

Received: 27 June 2017 / Accepted: 19 December 2017 / Published online: 1 February 2018

(C) Botanical Society of Sao Paulo 2018

\begin{abstract}
In fall 1995, during a survey in Abrolhos coral reef system (southwestern Atlantic, Brazil), significant densities (143-6174 cells $\mathrm{L}^{-1}$ ) of small thecate dinoflagellates were detected. Analysis of this material in scanning and transmission electron microscopy confirmed the presence of four taxa assigned to the potentially toxic genus Azadinium: A. dexteroporum Percopo et Zingone, A. luciferelloides Tillmann et Akselman, A. cf. polongum Tillmann and Azadinium sp. The latter taxon showed external morphological features quite distinct from any Azadinium taxon yet described, but its formal description as a new species depends on more detailed analysis. Species of Azadinium have never been confirmed in Brazilian waters until now, although the toxins produced by these dinoflagellates, the azaspiracids, have been detected in Brazilian southern coast without recognition of their producing organisms. The highest densities of Azadinium spp. occurred at stations south of and over the Abrolhos Bank, which receive higher nutrient concentrations due to upwelling of deep and nutrient-rich water masses.
\end{abstract}

Keywords Dinophyta $\cdot$ Electron microscopy $\cdot$ Harmful algae $\cdot$ Nanoplankton $\cdot$ South America

\section{Introduction}

Many dinoflagellate species are known as potential toxin producers and may cause serious ecological and economic losses in coastal regions around the world. Among them there are small thecate species of the genera Azadinium Elbrächter et Tillmann and Amphidoma F. Stein (Family Amphidomataceae), which can produce potent phycotoxins from the azaspiracid group (AZAs, Tillmann et al. 2009, 2014b; Krock et al. 2012). AZAs are lipophilic polyether toxins with more than 30 analogues known (Hess et al. 2014). AZAs accumulate in filter feeders, particularly bivalves' tissues, and may cause azaspiracid shellfish poisoning (AZP), a severe syndrome of gastrointestinal symptoms in humans who consumed contaminated

Kaoli Pereira Cavalcante

kaolicavalcante@gmail.com

1 Universidade Estadual de Santa Cruz, Rodovia Jorge Amado km 16, Salobrinho, Ilhéus, Bahia CEP: 45662900, Brazil

2 Alfred Wegener Institute Helmholtz Centre for Polar- and Marine Research, Am Handelshafen 12, 27570 Bremerhaven, Germany seafood. Similar to Diarrhetic Shellfish Toxins (DSP), human consumption of AZA-contaminated shellfish can result in severe acute symptoms that include nausea, vomiting, diarrhea, and stomach cramps (Twiner et al. 2014). Toxicological studies on animals showed "neurotoxin-like" symptoms in mice after i.p. injection characterized by sluggishness, respiratory difficulties, spasms, progressive paralysis, and death (Satake et al. 1998). Moreover, AZAs were shown to be teratogenic in fish (Colman et al. 2005), damaging to the gastrointestinal tract in mice (Ito et al. 2002), and to be potential lung tumor promoters (Furey et al. 2010). The first episode of human poisoning by azaspiracid was documented in Ireland in 1995 (McMahon and Silke 1996; Satake et al. 1998). Human poisoning incidents associated with this toxin group have since than been reported in Europe and in the USA, all of which were caused by shellfish harvested in Ireland (Twiner et al. 2014). However, AZA levels above the EU regulatory level have recently been reported from southern Spain as well (Tillmann et al. 2017a), indicating that AZP events may suddenly show up in previously unaffected areas. 
The first toxin-producing organism was only identified in 2009 (Tillmann et al. 2009). Azaspiracids have been recorded in many coastal regions of the world (e.g., James et al. 2002; Braña Magdalena et al. 2003; Taleb et al. 2006; Amzil et al. 2008; Elgarch et al. 2008; Vale et al. 2008; Álvarez et al. 2010; Yao et al. 2010; Trainer et al. 2013; Bacchiocchi et al. 2015; Turner and Goya 2015). This suggests that the dinoflagellates source species are widely distributed throughout the oceans as well, and indeed, records of Azadinium spp. have been increasingly reported since studies on the nanoplanktonic communities have advanced (Tillmann and Akselman 2016).

Azadinium spp. are predominantly small (10-15 $\mu \mathrm{m})$ photosynthetic species with a thin theca, which is difficult to see under light microscopy (LM). Typical Kofoidian

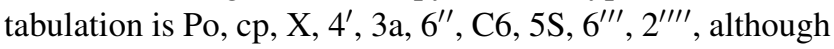
A. dalianense Z. Luo, H. Gu et Tillmann and A. zhuanum Z. Luo, Tillmann et $\mathrm{H}$. $\mathrm{Gu}$ have reduced numbers of epithecal plates (Luo et al. 2013, 2017). All known species have a distinct ventral pore of variable position among taxa (Tillmann et al. 2014b). Thirteen Azadinium taxa were described until now: A. spinosum Elbrächter et Tillmann (Tillmann et al. 2009), A. obesum Tillmann et Elbrächter (Tillmann et al. 2010), A. poporum Tillmann et Elbrächter (Tillmann et al. 2011), A. polongum Tillmann (Tillmann et al. 2012), A. caudatum (Halldal) Nézan et Chomérat var. caudatum, A. caudatum var. margalefii (Rampi) Nézan et Chomérat (Nézan et al. 2012), A. dexteroporum Percopo et Zingone (Percopo et al. 2013), A. dalianense (Luo et al. 2013), A. trinitatum Tillmann et Nézan, A. cuneatum Tillmann et Nézan, A. concinnum Tillmann et Nézan (Tillmann et al. 2014a), and the recently proposed $A$. luciferelloides Tillmann et Akselman (Tillmann and Akselman 2016) and A. zhuanum (Luo et al. 2017). Infrageneric taxa can be morphologically distinguished by a set of characters, such as presence of an antapical spine, size and shape of epithecal plates, number and arrangement of thecal pores and the position of the ventral pore (Tillmann and Akselman 2016).

Identification and knowledge of the potentially toxigenic species of Azadinium present in an area are an important prerequisite to evaluate the risk potential of AZP and to establish early warning monitoring programs in order to protect shellfish consumers. Although AZAs have already been found in the Brazilian coast (Schramm et al. 2010; Massucatto et al. 2014), no record of Azadinium spp. was published until now. Proença et al. (2014) preliminarily reported on isolation of an "Azadinium-like flagellate" from a shallow mangrove of southern Brazil with the presence of azaspiracid analogues, but this report was not conclusive and still is in need of confirmatory analyses. During observations on samples collected in an oceanographic cruise to the continental shelf of eastern Brazil in fall 1995, significant densities of small thecate dinoflagellates were detected. Morphological analysis of this material confirmed that those organisms are assigned to the genus Azadinium. This work now formally describes the first detection of Azadinium spp. along the Brazilian coast (southwestern Atlantic) and shows ecological data related to the occurrence of these species in a Brazilian tropical system.

\section{Materials and methods}

Samples are from a Brazilian-German Joint Oceanographic Project (JOPS-II-9), collected between April 25 and May 8, 1995, in Abrolhos region $\left(16-21.5^{\circ} \mathrm{S} ; 36-40.5^{\circ} \mathrm{W}\right)$. The Abrolhos Bank is a large extension of the eastern Brazilian continental shelf, which functions as a topographical barrier for the Brazil Current that flow southward (Ekau and Knoppers 1999). The main water masses in this region are the Brazil Current, a warm, saline oligotrophic tropical water (TW) mass, laying in the upper offshore hundred meters and being the major component of the coastal waters; and the South Atlantic Central Water (SACW), a deep cold and rich water mass flowing northward, that represents the main source of nutrients at the coastal upwelling south of the Abrolhos Bank (Gaeta et al. 1999). Additionally, shallow banks on tidal currents generate internal tides and upwelling over the southern flank of the Abrolhos Bank (Pereira et al. 2005).

Sampling was conducted at 16 stations at two depths: subsurface samples, corresponding to 50-25\% of the surface irradiance, and deep euphotic layer samples, with $10-1 \%$ of the light intensity (Fig. 1). The hydrographic structure of the area (water temperature and salinity) was obtained by lowering ME-CTD equipment from the surface down to a maximum depth of $450 \mathrm{~m}$. Nitrate, nitrite, phosphate, and silicate were measured by spectrophotometry (Grasshoff 1983), and chlorophyll-a concentration was estimated by fluorometry (Yentsch and Menzel 1963). Plankton was sampled with Niskin bottles. Two to fifteen liters of the plankton samples were immediately concentrated in the dark by gravity using Nuclepore polycarbonate membrane filters with $1 \mu \mathrm{m}$ pore size to a final volume of $250 \mathrm{~mL}$. Aliquots were preserved with buffered paraformaldehyde $(0.3 \%$ final concentration) and quantified in settling chambers using a Zeiss Axiovert -35 inverted light microscope (Utermöhl 1958).

For transmission electron microscopy (TEM), $10 \mathrm{~mL}$ of these samples were concentrated by centrifugation, prepared on grids covered with Formvar, air-dried at room temperature and observed in a PHILIPS CM-200 microscope. For scanning electron microscopy (SEM), subsamples of the plankton concentrate were fixed with glutaraldehyde $(2.5 \%$ final concentration $)$ in sodium 
Fig. 1 Study area showing numbered sampling stations in Abrolhos Bank, eastern Brazilian continental shelf. Dashed lines correspond to $100 \mathrm{~m}$ isobaths

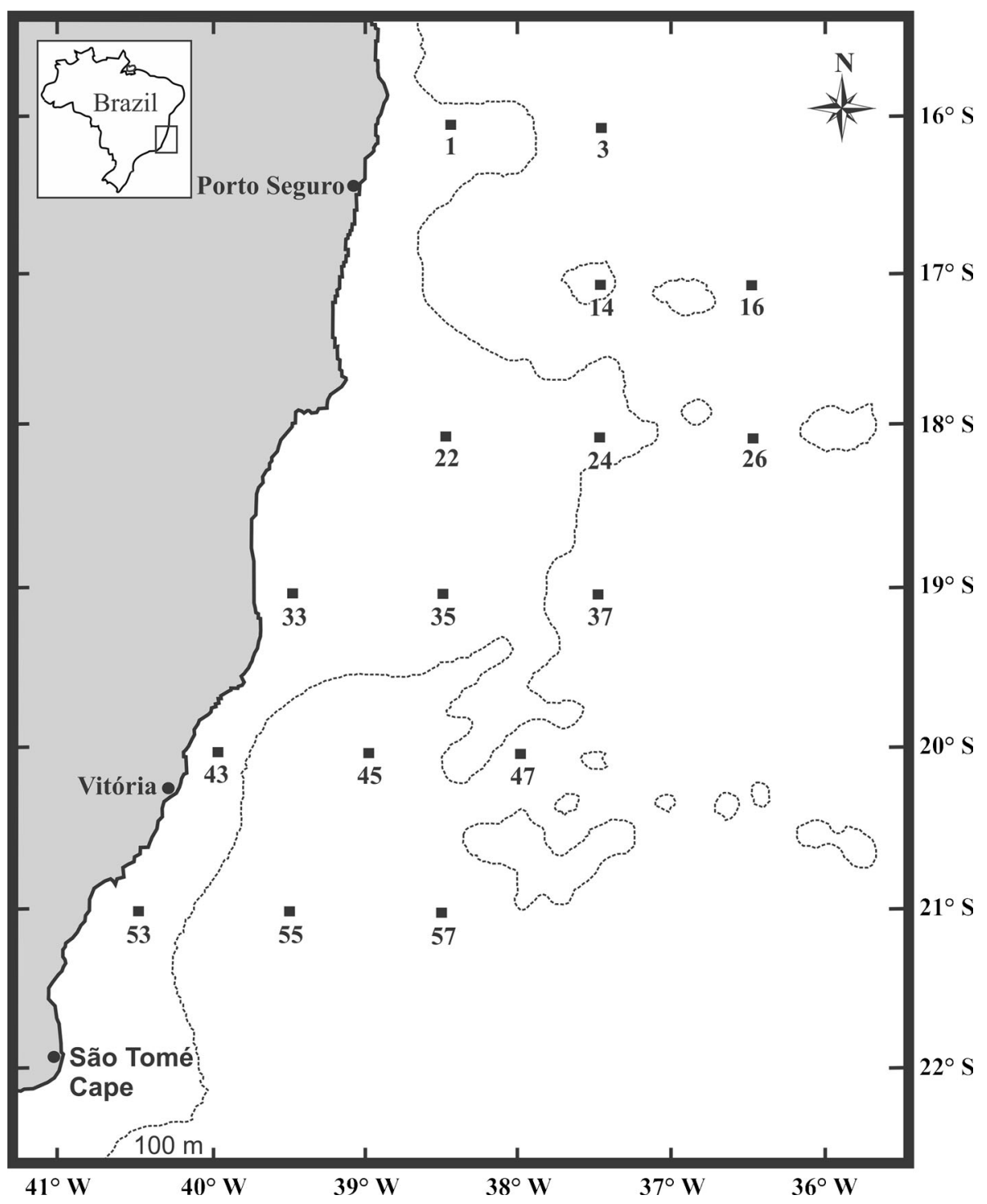

layers, evidence the influence of TW from Brazil Current. Nutrients ranged approximately in a tenfold difference from lowest to highest values, except by nitrate, which showed wider variation in different stations. Silicate showed the highest mean level among the nutrient analyzed. Higher chlorophyll- $a$ contents $\left(>0.2 \mathrm{mg} \mathrm{m}^{-3}\right)$ were related to stations south of Abrolhos Bank (especially at the deep euphotic layer) and over the bank.

Because of the small size of the cells and because species-specific features are almost indistinguishable in LM, nanodinoflagellate counts were categorized by shape and size. In these categories, dinoflagellate cells which were Azadinium-like in shape and $7-15 \mu \mathrm{m}$ long ranged from 143 to 6174 cells $\mathrm{L}^{-1}$ (Fig. 2). The highest cell densities were observed at subsurface of stations $22(1 \mathrm{~m}$, 6174 cells $\left.\mathrm{L}^{-1}\right)$, and $24\left(10 \mathrm{~m}, 3812\right.$ cells $\left.\mathrm{L}^{-1}\right)$ over the central zone in the bank and at stations $43(10 \mathrm{~m}$,
Environmental data of the field sampling campaign are summarized in Table 1. High temperature and salinity associated with low nutrient content, especially in surface 
Table 1 Range, mean values, and standard deviation (SD) of environmental variables in this study

Fig. 2 Density (cells $\mathrm{L}^{-1}$ ) of Azadinium-like cells at subsurface and deep euphotic layers by station in Abrolhos Bank

\begin{tabular}{|c|c|c|c|c|c|c|}
\hline & \multicolumn{3}{|c|}{ Subsurface $(n=16)$} & \multicolumn{3}{|c|}{ Deep euphotic layer $(n=16)$} \\
\hline & Min-Max & Mean & SD & Min-Max & Mean & SD \\
\hline Temperature $\left({ }^{\circ} \mathrm{C}\right)$ & $24.70-28.26$ & 27.22 & 1.02 & $21.34-28.21$ & 25.12 & 2.03 \\
\hline Salinity & $36.33-37.40$ & 36.99 & 0.28 & $36.36-37.14$ & 36.82 & 0.24 \\
\hline $\mathrm{NO}_{2}(\mu \mathrm{M})$ & $<0.01-0.14$ & 0.04 & 0.03 & $<0.01-0.14$ & 0.06 & 0.04 \\
\hline $\mathrm{NO}_{3}(\mu \mathrm{M})$ & $0.04-4.78$ & 0.77 & 1.24 & $0.12-2.88$ & 1.08 & 0.94 \\
\hline $\mathrm{PO}_{4}(\mu \mathrm{M})$ & $0.05-0.46$ & 0.12 & 0.10 & $0.07-0.32$ & 0.15 & 0.07 \\
\hline $\mathrm{Si}(\mathrm{OH})_{4}(\mu \mathrm{M})$ & $0.63-5.86$ & 2.08 & 1.55 & $0.77-7.20$ & 2.79 & 2.15 \\
\hline Chlorophyll- $a\left(\mathrm{mg} \mathrm{m}^{-3}\right)$ & $0.06-0.40$ & 0.16 & 0.09 & $0.07-0.53$ & 0.25 & 0.13 \\
\hline
\end{tabular}

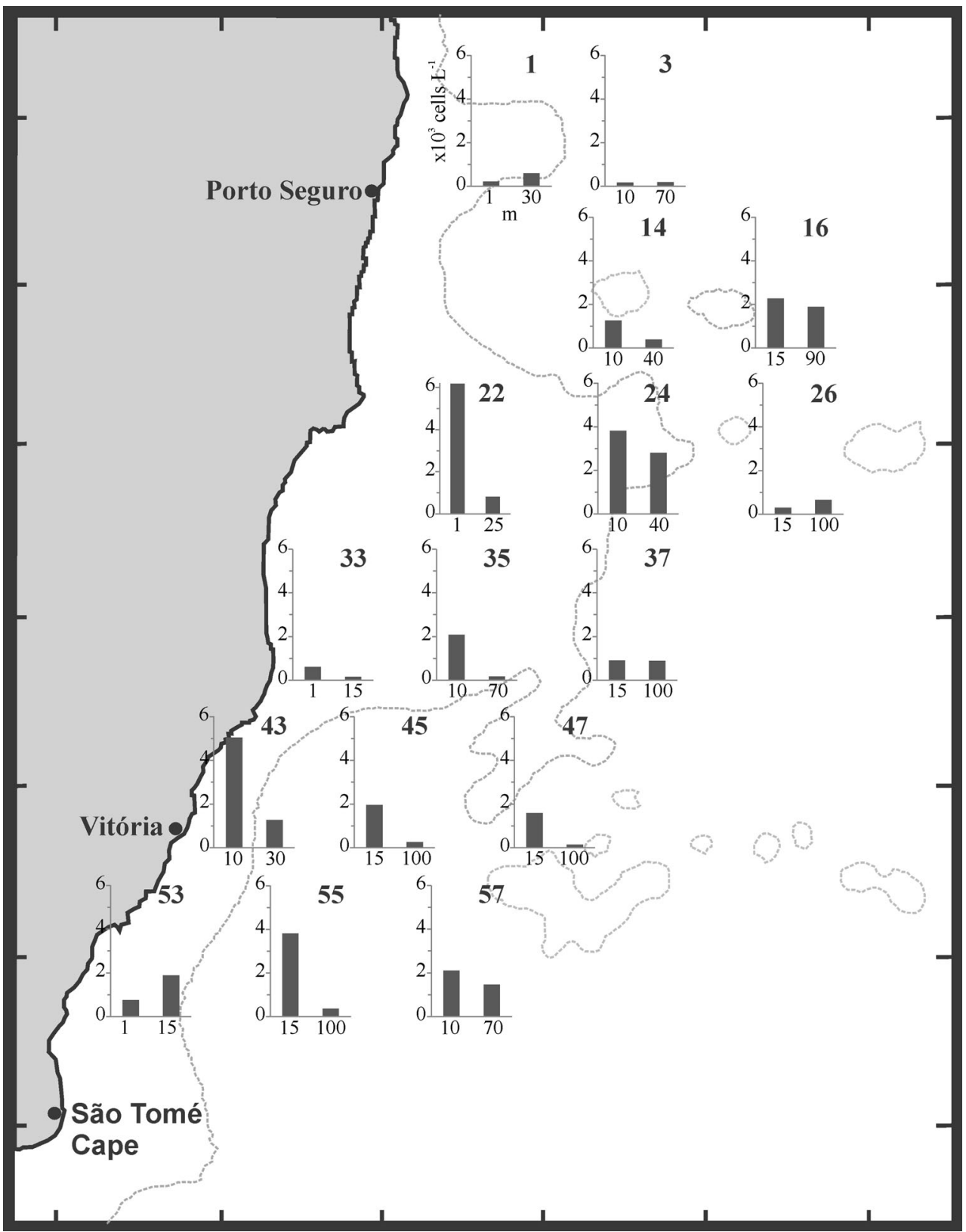


5044 cells $\left.\mathrm{L}^{-1}\right)$ and $55\left(15 \mathrm{~m}, 3812\right.$ cells $\left.\mathrm{L}^{-1}\right)$ at south of the bank.

SEM and TEM analysis revealed at least four taxa assigned to the genus Azadinium in the samples, which are described below:

Azadinium dexteroporum Percopo et Zingone (in Percopo et al. 2013, J. Phycol. 49, p. 953, Figs. 1-6) (Fig. 3).

Small cell, $7.5 \mu \mathrm{m}$ long, $5.4 \mu \mathrm{m}$ wide in SEM image $(n=1)$; epitheca conical, hypotheca hemispherical; cingulum wide and excavated; ventral view not observed; the identification is based on the typical rectangular and concave shape of plate $2 \mathrm{a}$; precingular plates high and antapical spine $(0.5 \mu \mathrm{m}$ long $)$ located at the right side of the cell.
Azadinium luciferelloides Tillmann et Akselman (in Tillmann and Akselman 2016, Phycol. Res. 64, p. 162, Figs. 1-5) (Figs. 4-6).

Small cells, $8-11 \mu \mathrm{m}$ long, $5.3-8.8 \mu \mathrm{m}$ wide in SEM images $(n=4)$; epitheca conical, hypotheca hemispherical; cingulum wide and excavated; sulcus not reaching the antapex; plate $1^{\prime}$ narrow; ventral pore located at right ventral edge of the pore plate; precingular plates wide; small antapical spine (ca. $0.5 \mu \mathrm{m}$ long) at right of the cell, emerging from the plate $2^{\prime \prime \prime \prime}$.

Azadinium cf. polongum Tillmann (in Tillmann et al. 2012, Harmful Algae 20, p. 145, Figs. 1-7) (Figs. 7-10).

Small cell, ca. $10 \mu \mathrm{m}$ long and $7 \mu \mathrm{m}$ wide in TEM image $(n=1)$; epitheca conical, hypotheca hemispherical;
Figs. 3-6 Azadinium spp. in SEM. 3 A. dexteroporum in dorsal view. 4-6

A. luciferelloides in ventral view (4), dorsal-lateral view, showing hypothecal tabulation (5), and ventral view of epitheca (6). $\mathrm{vp}=$ ventral pore. Scale bars $=2 \mu \mathrm{m}$
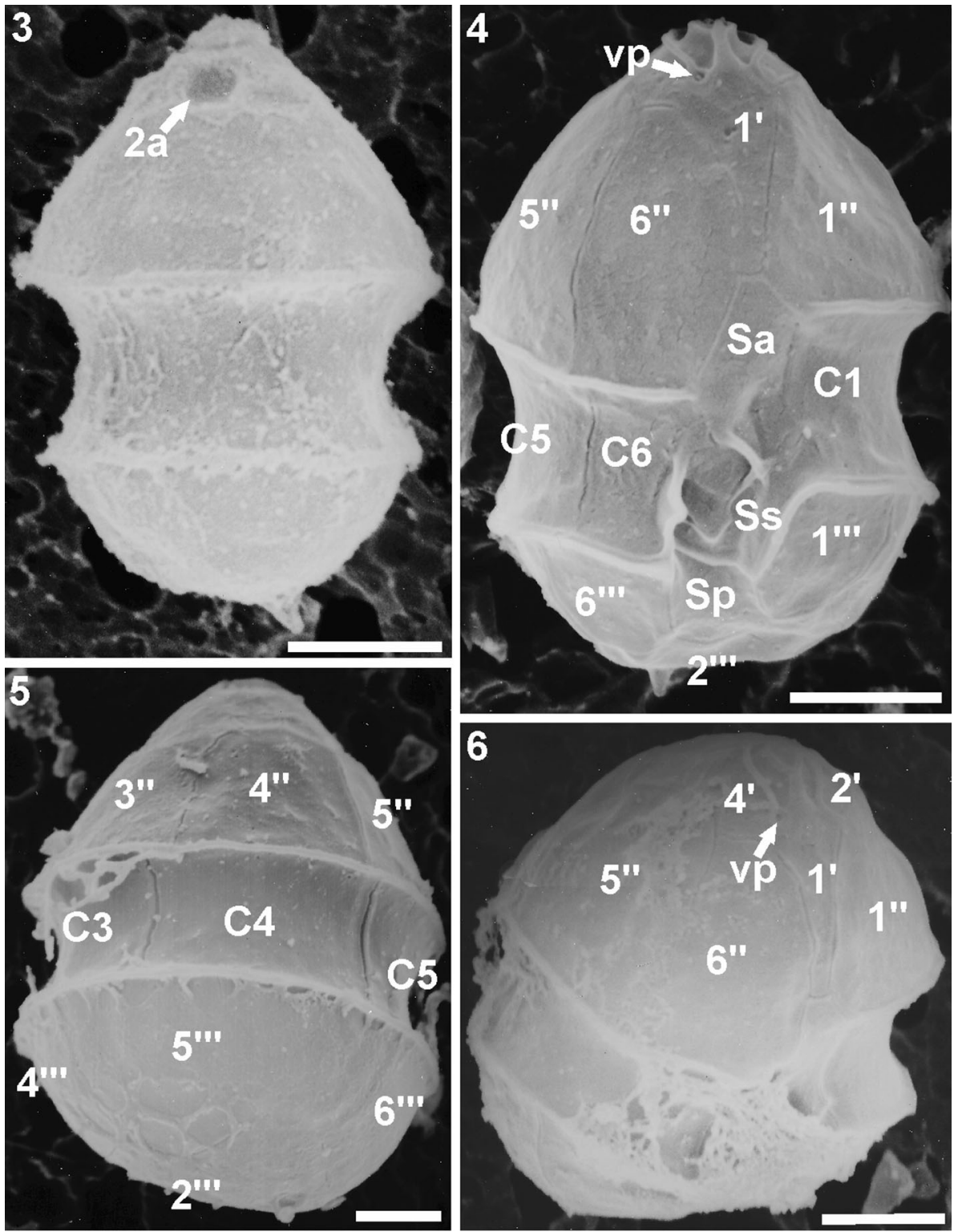
Figs. 7-10 Azadinium cf. polongum. 7, $8 \mathrm{~A}$. cf. polongum in ventral view (7) and detail of the ventral pore (8), TEM. 9, 10. Schematic representation of our interpretation on the tabulation in $\mathbf{7}$, ventral view (9) and dorsal view (10), seen by transparency. Dashed lines indicate sutures assumed but not clearly visible in the image. Scale bars $=2 \mu \mathrm{m}(7)$ and $500 \mathrm{~nm}$ (8)
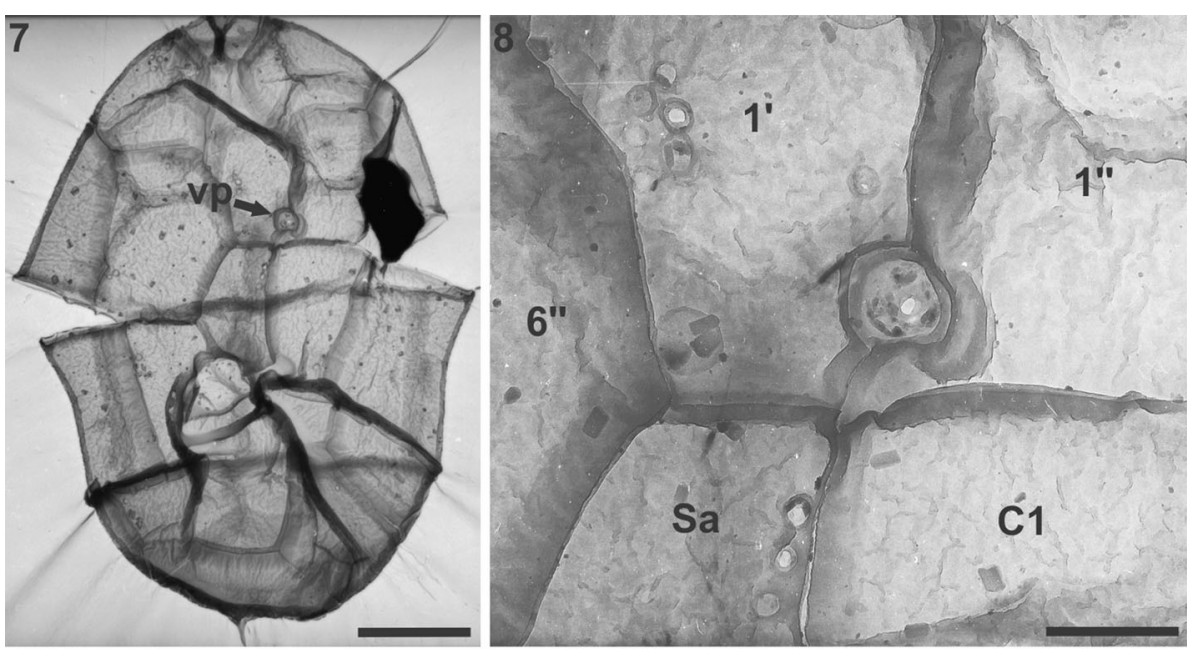

9

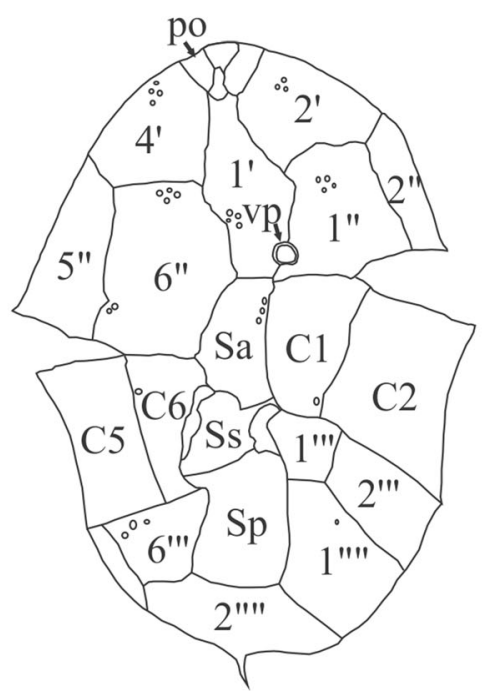

10

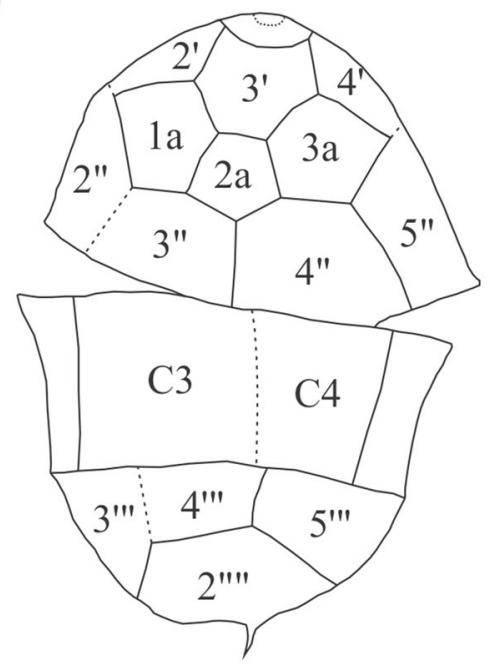

cingulum wide and excavated; sulcus not reaching the antapex; ventral pore located at lower left margin of a wide plate $1^{\prime}$ on the suture with the plate $1^{\prime \prime}$; intercalary plates median in dorsal epitheca (seen by transparency), 2a pentagonal, slightly smaller than 1a and 3a; 1a not in contact to $1^{\prime \prime}$; medium-size antapical spine (ca. $0.6 \mu \mathrm{m}$ long), located on the right (almost center) of the hypotheca, emerging from plate $2^{\prime \prime \prime \prime}$.

\section{Azadinium sp. (Figs. 11-13).}

Small cells, 9.8-11.8 $\mu \mathrm{m}$ long, 7.8-8.7 $\mu \mathrm{m}$ wide in SEM images $(n=2)$; epitheca conical, hypotheca hemispherical; cingulum wide and excavated; sulcus wide, not reaching the antapex; ventral pore located at lower left margin of a wide plate $1^{\prime}$; plate $1^{\prime}$ with a dense group of small pores; plate $2 \mathrm{a}$ small and square, median in dorsal epitheca; plate $3 \mathrm{a}$ large, with posterior end close to cingulum edge and contacting the tip of a small triangular precingular plate $4^{\prime \prime}$; large antapical spine $(0.8-1.0 \mu \mathrm{m}$ long) displaced to the left side of the cell emerging from plate $2^{\prime \prime \prime \prime}$.

\section{Discussion}

The identity of the taxa - In fact, the taxa reported here belong to the genus Azadinium, based on small size, thecal plate formula, and typical features such as presence of a distinct ventral pore, the apical pore complex structure, with X plate forming a finger-like protrusion in contact to the cover plate, and the sulcal plate Ss running from the cingular plate C1 to C6 (Tillmann et al. 2009; Nézan et al. 2012). Generally, taxa of Azadinium at infrageneric level are quite similar, but some key features are proven to be sufficiently conservative among species and are often used in a morphotaxonomic approach (Nézan et al. 2012; Tillmann and Akselman 2016), such as the position of the ventral pore, size, shape and arrangement of intercalary plates, pattern of thecal pores and presence of an antapical 

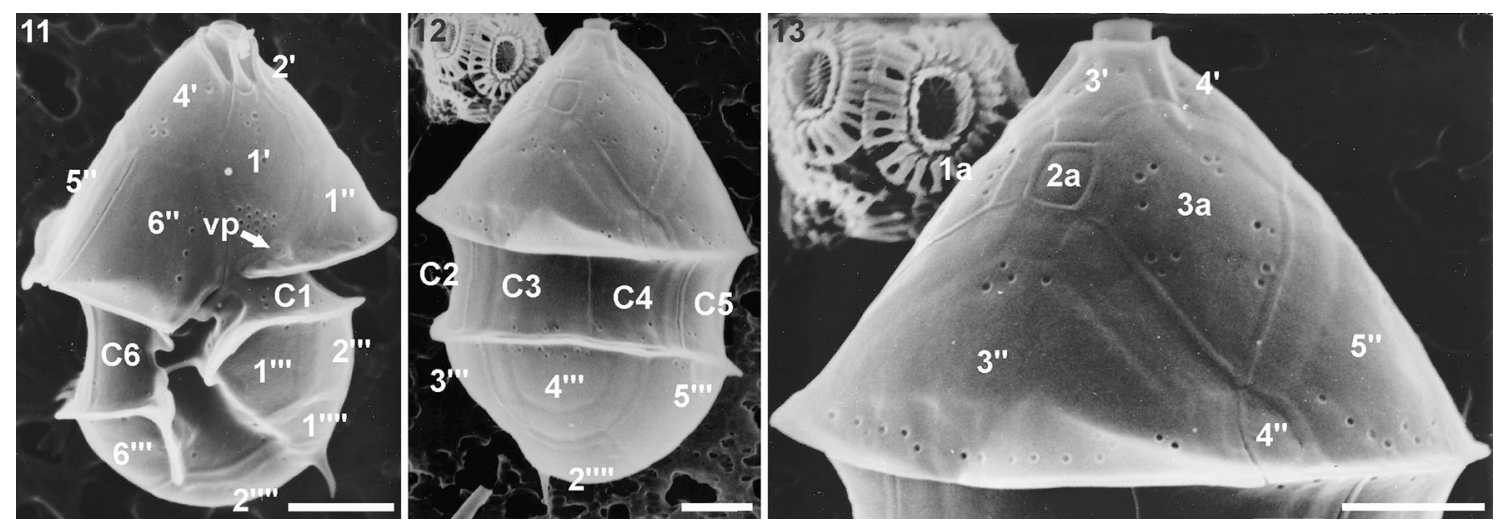

Figs. 11-13 Azadinium sp. in ventral (11), dorsal (12) and detail of dorsal view of epitheca (13), SEM. $v p=$ ventral pore. Scale bars $=2 \mu \mathrm{m}$

spine (Tillmann et al. 2014b; Tillmann and Akselman 2016).

Azadinium dexteroporum was identified in this study by a unique feature only found in this species so far: the typical concave plate $2 \mathrm{a}$. This character is quite conservative in the type material (Percopo et al. 2013) as well as in specimens recorded from the Argentinean shelf (Tillmann and Akselman 2016), although a subarctic strain identified as $A$. dexteroporum showed a flat plate $2 \mathrm{a}$ (Tillmann et al. 2015). Other features, such as high precingular plates, presence of an antapical spine on the right side of the cell and the smaller size (Percopo et al. 2013), as well as the confirmed presence of this taxon in the southwest Atlantic (Tillmann and Akselman 2016) support this identification.

A newly described species forming blooms in Argentinean middle shelf waters, Azadinium luciferelloides (Tillmann and Akselman 2016), was also recorded in this study. This species can be distinguished from others by a ventral pore located at right to the pore plate, contacting the suture between the plates $1^{\prime}$ and $4^{\prime}$; plate $1^{\prime}$ is narrow, rhomboid and slightly asymmetrical; and a short spine is present on the antapical plate $2^{\prime \prime \prime \prime}$, at right of the theca (Tillmann and Akselman 2016).

Azadinium spinosum and A. polongum are the only taxa so far described as having both a ventral pore located at left margin of the plate $1^{\prime}$ and an antapical spine slightly positioned at the right side of the cell (Tillmann et al. 2009, 2012). However, differences in the shape of the pore plate, in the position of the ventral pore, and in the arrangement of the dorsal epithecal intercalary plates are important in distinction of these species. A. spinosum is characterized by a round pore plate, by a ventral pore inserted on the plate $1^{\prime}$ close to (but not on) the suture with the plate $1^{\prime \prime}$, and by a hexagonal plate $3^{\prime}$ which is almost as high as the plate $2 \mathrm{a}$ (Tillmann et al. 2009). In contrast, $A$. polongum has an elongated pore plate, a ventral pore which is more posteriorly positioned in the epitheca and which insert on the suture between $1^{\prime}$ and $1^{\prime \prime}$ forming a cavity in plate $1^{\prime \prime}$, and a plate $3^{\prime}$ with a narrow base which is linked to a more minute plate $2 \mathrm{a}$ (Tillmann et al. 2012). The ventral view of the single cell of $A$. cf. polongum recorded in this study conforms to the major features of the latter species, except by shape and size of the plates $3^{\prime}$ and $2 \mathrm{a}$. However, these observations should be considered with caution, since the only specimen observed is collapsed and the shape of the plates may be slightly altered. Another interesting feature of the cell of $A$. cf. polongum observed here is that $1^{\prime \prime}$ does not contact $1 \mathrm{a}$. Such a contact was described for the type material of A. polongum (Tillmann et al. 2012), but without exception was missing for a Pacific field population of A. polongum (Tillmann et al. in revision). In any case, morphological observations of more Brazilian specimens and ultimately molecular data are needed for unequivocal identification of this taxon.

The taxon identified here as Azadinium sp. shows external morphological features quite distinct from any Azadinium taxon yet described. The position of the antapical spine very distinctly is displaced to the left of the sulcus. Within Azadinium an antapical spine position slightly left of the sulcus can be seen for the two varieties of A. caudatum, which also have an exceptionally small and three-sided plate $4^{\prime}$ and a very minute (compared to the other epithecal intercalary plates) central epithecal intercalary plate (Nézan et al. 2012). Moreover, for A. caudatum the rim running around the pore plate extend on the dorsal side alongside the anterior margins of plate $3^{\prime}$, a feature which is also present in the specimen of Azadinium sp. depicted in Figs. 12-13. Based on these similarities a close relation between Azadinium caudatum and Azadinum sp. might be anticipated. However, the overall shape and size of the cell as well as the arrangement of the thecal plates and pores are evidently different between A. caudatum and Azadinium sp. The elongated $\mathrm{X}$ and pore plates, and the position of ventral pore are very similar to $A$. polongum. However, compared to A. polongum, Azadinium 
sp. showed a more conical epitheca, and the plate $\mathrm{Sp}$ is apparently larger, with the margin contacting the plate $2^{\prime \prime \prime \prime}$ being expressively longer than the suture with the plate $1^{\prime \prime \prime \prime}$. Moreover, the antapical spine at left of the sulcus and the size and shape of $4^{\prime \prime}$ are important differences between these taxa. A feature of Azadinium sp. not described for other species of Azadinium is the presence of a group of pores in the posterior part of plate $1^{\prime}$. In conclusion of all morphological details, this taxon seems to be new to science. Previous Azadinium species were described based on morphology and molecular data obtained from cultured material. The only exception is A. luciferelloides, which was described from a field bloom sample, where the cell number was sufficiently high to evaluate the extent of variation of the observed diacritical features (Tillmann and Akselman 2016). Up to now, our observations about the potentially new Azadinium taxon reported here are rather limited and insufficient to evaluate if the morphological differences are conserved in a population. A formal description of this taxon will thus be put on hold until new material for more detailed analysis is available.

Distribution and ecology of Azadinium spp. - In the upper mixed layer of Abrolhos Bank region, cell densities of Azadinium spp. with maximum of $6 \times 10^{3}$ cells $\mathrm{L}^{-1}$ were found at fall, at temperatures between 21 and $28{ }^{\circ} \mathrm{C}$, high salinity and rather low nutrient content (Table 1). In this time, cyanobacteria (64\%) and autotrophic nanoplankton $(31 \%)$ were quite representative of the total phytoplankton in carbon biomass (Susini-Ribeiro 1996, 1999). In addition, phytoplankton carbon biomass was twice as large on the south continental shelf and on the Abrolhos Bank as in the open ocean (Susini-Ribeiro 1999). Similar pattern were observed in the density and distribution of Azadinium (Fig. 2) and also of diatoms. The diatoms were more abundant in stations near the coast than offshore. In coastal stations microplanktonic diatoms were most abundant whereas in offshore oceanic stations nanoplanktonic forms predominated (Susini-Ribeiro 1996). A relatively low phytoplankton biomass associated with a high contribution of nanoplanktonic forms in the Abrolhos region is related to the predominance of the oligotrophic, warm and saline tropical water mass from Brazil Current. However, the phototrophic fraction of the micro- and nanoplankton increases in the southern area and over the Abrolhos Bank. In these regions, the input of deep and nutrient-rich water masses originating from SACW justifies an increase in productivity (Susini-Ribeiro 1999; SusiniRibeiro et al. 2013).

Studies about the spatial and temporal dynamics of Azadinium species are scarce, especially due to their small size (about $15 \mu \mathrm{m}$ length) and the impossibility of an accurate identification during routine quantification at LM
(Tillmann et al. 2014b). Most of the information on the spatial and temporal distribution of Azadinium was indirectly inferred by AZA toxins detection (Krock et al. 2013; Tillmann et al. 2014b). In the North Sea, AZA distribution indicated that Azadinium populations were more common in the mid to late boreal summer (Tillmann et al. 2014b). Similarly, in northwestern coast of Morocco, maximal concentration of AZAs occurred in July (Taleb et al. 2006). Extensive blooms forming brownish-red patches ca. $60 \mathrm{~km}$ long occurred in the northern shelf of Argentina during austral spring at rather low water temperature $\left(8-9{ }^{\circ} \mathrm{C}\right)$ and salinity $(\sim 33.7)$ and high nitrate content $(>3 \mu \mathrm{M})$, with maximum Azadinium cell density estimated as $9 \times 10^{6}$ cells L ${ }^{-1}$ (Akselman and Negri 2012). According to these authors, Azadinium biomass in spring can be greater than typical density of spring-bloom diatoms of the genus Thalassiosira, presenting the highest Azadinium bloom density known so far.

In many coastal areas of the world, the detection of azaspiracids in shellfish tissues preceded the isolation and identification of the producer organism (Tillmann and Akselman 2016; Tillmann et al. 2017b), and we have the same progression for Brazil. While our samples were taken already in 1995, we only now have accurately determined the first observation of these algae in Brazilian coastal waters. This is partially due to scarcity of researches focusing on the nanoplanktonic size fraction in this region.

Among the four Azadinium taxa reported here, AZA production is only confirmed for one of them. The type culture of A. dexteroporum from the Mediterranean produces seven (six of which are new to science) different AZAs (Rossi et al. 2017), but a strain from the subarctic Irminger Sea determined as A. dexteroporum clearly lack any of these or other known AZA (Tillmann et al. 2015). For A. polongum, the type strain from the Northeast Atlantic is negative for AZAs (Tillmann et al. 2012) and a bloom sample with $1 \times 10^{6}$ cells $\mathrm{L}^{-1}$ of $A$. polongum from the Pacific coast of Peru was negative for AZAs (Tillmann et al. in revision). For both A. luciferelloides and Azadinium sp. the AZA production potential is unknown due to the lack of cultured strains.

The knowledge on which AZAs are present in Brazil is rather limited. Azaspiracids have been preliminary detected along the Brazilian southern coast since 2009 in mussels (Schramm et al. 2010), oysters and crabs (Massucatto et al. 2014). The latter authors reported on the presence of six AZAs, with AZA-2 being known as a compound produced by Azadinium poporum (Tillmann et al. 2016) and the other AZAs being known as shellfish metabolites. In contrast, Schramm et al. (2010) reported the presence of AZA-1 and -2, and AZA-1 up to now is only known to be produced by A. spinosum (Hess et al. 2014). Merging our first data on Azadinium diversity with these preliminary 
toxin data indicate that both, yet unreported AZAs (as inferred from the presence of $A$. dexteroporum), and yet undetected species (as inferred from the presence of AZA1 and -2) might be present in Brazil. In any case, in order to evaluate the local AZA production potential, Brazilian strains need to be established and analyzed, as AZA-producing strains and non-toxigenic strains within the same species are known for the genus Azadinium (Krock et al. 2014; Tillmann et al. 2015; Rossi et al. 2017).

Our SEM and TEM analysis indicates that in Brazil several species of Azadinium co-occur in the environment. A high diversity of species of Azadinium in the same area has been emphasized for other areas as well (Tillmann et al. 2010, 2014a; Nézan et al. 2012; Tillmann and Akselman 2016), which makes it generally difficult to identify, quantify, and distinguish between toxic and nontoxic species in light microscopy-based monitoring programs. The Azadinium sp. recorded here shows morphological features divergent from others described species, with high potential to be new to science. Altogether, the presented findings corroborate the current notion (Tillmann and Akselman 2016) that the actual distribution and diversity of Azadinium species remains underexploited.

Acknowledgements The JOPS-II Project was financed by the Ministries of Science and Technology of Brazil (MCT and MMA/ IBAMA) and Germany (BMBF, Project No. 03f0144A). Sylvia Maria Moreira Susini-Ribeiro was supported by FAPESP (No. 93/2907-8) and $\mathrm{CNPq}$ Research grant. Special thanks are given to Drs. Salvador Airton Gaeta and Mayza Pompeu for providing all oceanographic datasets used in this paper.

\section{References}

Akselman R, Negri RM (2012) Blooms of Azadinium cf. spinosum Elbrächter et Tillmann (Dinophyceae) in northern shelf waters of Argentina, Southwestern Atlantic. Harmful Algae 19:30-38. https://doi.org/10.1016/j.hal.2012.05.004

Álvarez G, Uribe E, Ávalos P, Mariño C, Blanco J (2010) First identification of azaspiracid and spirolides in Mesodesma donacium and Mulinia edulis from Northern Chile. Toxicon 55:638-641. https://doi.org/10.1016/j.toxicon.2009.07.014

Amzil Z, Sibat M, Royer F, Savar V (2008) First report on azaspiracid and yessotoxin groups detection in French shellfish. Toxicon 52:39-48. https://doi.org/10.1016/j.toxicon.2008.05.006

Bacchiocchi S, Siracusa M, Ruzzi A, Gorbi S, Ercolessi M, Cosentino MA, Ammazzalorso P, Orletti R (2015) Two-year study of lipophilic marine toxin profile in mussels of the North-central Adriatic Sea: first report of azaspiracids in Mediterranean seafood. Toxicon 108:115-125. https://doi.org/10.1016/j.toxi con.2015.10.002

Braña Magdalena A, Lehane M, Krys S, Fernández ML, Furey A, James KJ (2003) The first identification of azaspiracids in shellfish from France and Spain. Toxicon 42:105-108. https:// doi.org/10.1016/S0041-0101(03)00105-3

Colman JR, Twiner MJ, Hess P, McMahon P, Satake M, Yasumoto T, Doucette GJ, Ramsdell SJ (2005) Teratogenic effects of azaspiracid-1 identified by microinjection of Japanese medaka
(Oryzias latipes) embryos. Toxicon 45:881-890. https://doi.org/ 10.1016/j.toxicon.2005.02.014

Ekau W, Knoppers B (1999) An introduction to the pelagic system of the North-East and East Brazilian shelf. Arch Fish Mar Res 47:113-119

Elgarch A, Vale P, Rifai S, Fassouane A (2008) Detection of diarrheic shellfish poisoning and azaspiracid toxins in Moroccan mussels: comparison of the LC-MS method with the commercial immunoassay kit. Mar Drugs 6:587-594. https://doi.org/10. 3390/md6040587

Furey A, O’Doherty S, O'Callaghan K, Lehane M, James KJ (2010) Azaspiracid poisoning (AZP) toxins in shellfish: toxicological and health considerations. Toxicon 56:173-190. https://doi.org/ 10.1016/j.toxicon.2009.09.009

Gaeta SA, Lorenzzetti JA, Miranda LB, Susini-Ribeiro SMM, Pompeu M, Araujo CES (1999) The Vitória Eddy and its relation to the phytoplankton biomass and primary productivity during the austral fall of 1995. Arch Fish Mar Res 47:253-270

Grasshoff K (1983) Methods for seawater analysis. Weissheim Verlag Chemie, New York

Hess P, McCarron P, Krock B, Kilcoyne J, Miles CO (2014) Azaspiracids: chemistry, biosynthesis, metabolism, and detection. In: Botana LM (ed) Seafood and freshwater toxins: phamacology, physiology, and detection. CRC Press, Boca Raton, pp 799-821

Ito E, Satake M, Ofuji K, Higashi M, Harigaya K, McMahon T, Yasumoto T (2002) Chronic effects in mice caused by oral administration of sublethal doses of azaspiracid, a new marine toxin isolated from mussels. Toxicon 40:193-203. https://doi. org/10.1016/S0041-0101(01)00226-4

James KJ, Furey A, Lehane M, Ramstad H, Aune T, Hovgaard P, Morris S, Higman W, Satake M, Yasumoto T (2002) First evidence of an extensive northern European distribution of azaspiracid poisoning (AZP) toxins in shellfish. Toxicon 40:909-915. https://doi.org/10.1016/S0041-0101(02)00082-X

Krock B, Tillmann U, Voß D, Koch BP, Salas R, Witt M, Potvin E, Jeong HJ (2012) New azaspiracids in Amphidomataceae (Dinophyceae). Toxicon 60:830-839. https://doi.org/10.1016/j.toxi con.2012.05.007

Krock B, Tillmann U, Alpermann TJ, Voß D, Zielinski O, Cembella AD (2013) Phycotoxin composition and distribution in plankton fractions from the German Bight and western Danish coast. J Plankton Res 35:1093-1108. https://doi.org/10.1093/plankt/ fbt054

Krock B, Tillmann U, Witt M, Gu H (2014) Azaspiracid variability of Azadinium poporum (Dinophyceae) from the China Sea. Harmful Algae 36:22-28. https://doi.org/10.1016/j.hal.2014.04.012

Luo Z, Gu H, Krock B, Tillmann U (2013) Azadinium dalianense, a new dinoflagellate species from the Yellow Sea, China. Phycologia 52:625-636. https://doi.org/10.2216/13-178.1

Luo Z, Krock B, Mertens KN, Nézan E, Chomérat N, Bilien G, Tillmann U, Gu H (2017) Adding new pieces to the Azadinium (Dinophyceae) diversity and biogeography puzzle: non-toxigenic Azadinium zhuanum sp. nov. from China, toxigenic A. poporum from the Mediterranean, and a non-toxigenic A. dalianense from the French Atlantic. Harmful Algae 66:65-78. https://doi.org/10. 1016/j.hal.2017.05.001

Massucatto A, Pilotto ALS, Schramm MA (2014) Investigação da presença de azaspirácidos em recursos pesqueiros do Canal do Linguado. In: Resumos do $4^{\circ}$ Seminário de Pesquisa, Extensão e Inovação do Instituto Federal de Santa Catarina. IFSC, Florianópolis, pp 1-3

McMahon T, Silke J (1996) West coast of Ireland; winter toxicity of unknown aetiology in mussels. Harmful Algae News 14:2

Nézan E, Tillmann U, Bilien G, Boulben S, Chèze K, Zentz F, Salas R, Chomérat N (2012) Taxonomic revision of the dinoflagellate 
Amphidoma caudata: transfer to the genus Azadinium (Dinophyceae) and proposal of two varieties, based on morphological and molecular phylogenetic analyses. J Phycol 48:925-939. https://doi.org/10.1111/j.1529-8817.2012.01159.x

Percopo I, Siano R, Rossi R, Soprano V, Sarno D, Zingone A (2013) A new potentially toxic Azadinium species (Dinophyceae) from the Mediterranean Sea. A. dexteroporum sp. nov. J Phycol 49:950-966. https://doi.org/10.1111/jpy.12104

Pereira AF, Belém AL, Castro BM, Geremias R (2005) Tidetopography interaction along the eastern Brazilian shelf. Cont Shelf Res 25:1521-1539. https://doi.org/10.1016/j.csr.2005.04. 008

Proença LAO, Schramm MA, Santos KRS, Martins H, Alves TP, Menezes M (2014) Azaspiracid production by an Azadinium like flagellate isolated from a shallow mixosohaline mangrove system at southern Brazilian coast. In: Proceedings of 16th international conference on harmful algae. ISSHA, Wellington, p 121

Rossi R, Dell'aversano C, Krock B, Ciminiello P, Percopo I, Tillmann U, Soprano V, Zingone A (2017) Mediterranean Azadinium dexteroporum (Dinophyceae) produces AZA-35 and six novel azaspiracids: a structural study by a multi-platform mass spectrometry approach. Anal Bioanal Chem 409:1121-1134. https://doi.org/10.1007/s00216-016-0037-4

Satake M, Ofuji K, Naoki H, James KJ, Furey A, McMahon T, Silke J, Yasumoto T (1998) Azaspiracid, a new marine toxin having unique spiro ring assemblies, isolated from irish mussels, Mytilus edulis. J Am Chem Soc 120:9967-9968. https://doi.org/10.1021/ ja981413r

Schramm MA, Alves TP, Honorato MC, Proença LAO (2010) Primeira detecção de ficotoxinas lipofílicas em mexilhões da Armação do Itapocorói em Santa Catarina através de LC-MS/ MS. In: Anais do XIII Congresso Brasileiro de Ficologia. Sociedade Brasileira de Ficologia, Paraty, p 381

Susini-Ribeiro SMM (1996) Caracterização taxonômica e ecológica das comunidades pico-, nano- e microplanctônicas, superficial e profunda, da zona eufótica do Atlântico Sul. Ph.D. thesis, Universidade de São Paulo, São Paulo

Susini-Ribeiro SMM (1999) Biomass distribution of pico-, nano- and microplankton on the continental shelf of Abrolhos, East Brazil. Arch Fish Mar Res 47:271-284

Susini-Ribeiro SMM, Pompeu M, Gaeta SA, Souza JSD, Masuda LSD (2013) Topographical and hydrological impacts on the structure of microphytoplankton assemblages on the Abrolhos Bank region, Brazil. Cont Shelf Res 70:88-96. https://doi.org/10. 1016/J.csr.2013.09.023

Taleb H, Vale P, Amanhir R, Benhadouch A, Sagou R, Chafik A (2006) First detection of azaspiracids in mussels in north west Africa. J Res 25:1067-1070. https://doi.org/10.2983/07308000(2006)25[1067:FDOAIM]2.0.CO;2

Tillmann U, Akselman R (2016) Revisiting the 1991 algal bloom in shelf waters off Argentina: Azadinium luciferelloides sp. nov. (Amphidomataceae, Dinophyceae) as the causative species in a diverse community of other amphidomataceans. Phycol Res 64:160-175. https://doi.org/10.1111/pre.12133

Tillmann U, Elbrächter M, Krock B, John U, Cembella A (2009) Azadinium spinosum gen. et sp. nov. (Dinophyceae) identified as a primary producer of azaspiracid toxins. Eur J Phycol 44:63-79. https://doi.org/10.1080/09670260802578534

Tillmann U, Elbrächter M, John U, Krock B, Cembella A (2010) Azadinium obesum (Dinophyceae), a new nontoxic species in the genus that can produce azaspiracid toxins. Phycologia 49:169-182. https://doi.org/10.2216/PH09-35.1

Tillmann U, Elbrächter M, John U, Krock B (2011) A new non-toxic species in the dinoflagellate genus Azadinium: A. poporum sp. nov. Eur J Phycol 46:74-87. https://doi.org/10.1080/09670262. 2011.556753

Tillmann U, Söhner S, Nézan E, Krock B (2012) First record of Azadinium from the Shetland Islands including the description of A. polongum sp. nov. Harmful Algae 20:142-155. https://doi. org/10.1016/j.hal.2012.10.001

Tillmann U, Gottschling M, Nézan E, Krock B, Bilien G (2014a) Morphological and molecular characterization of three new Azadinium species (Amphidomataceae, Dinophyceae) from the Irminger Sea. Protist 165:417-444. https://doi.org/10.1016/j. protis.2014.04.004

Tillmann U, Salas R, Jauffrais T, Hess P, Silke J (2014b) AZA: the producing organisms-biology and trophic transfer. In: Botana LM (ed) Seafood and freshwater toxins. CRC Press, Boca Raton, pp 773-798

Tillmann U, Gottschling M, Nézan E, Krock B (2015) First record of Azadinium dexteroporum and Amphidoma languida (Amphidomataceae, Dinophyceae) from the Irminger Sea off Iceland. Mar Biodivers Rec 8:1-11. https://doi.org/10.1017/ S1755267215001128

Tillmann U, Borel CM, Barrera F, Lara R, Krock B, Almandoz GO, Witt M, Trefault N (2016) Azadinium poporum from the Argentine Continental Shelf, Southwestern Atlantic, produces azaspiracid-2 and azaspiracid-2 phosphate. Harmful Algae 51:40-55. https://doi.org/10.1016/j.hal.2015.11.001

Tillmann U, Jaén D, Fernández L, Gottschling M, Witt M, Blanco J, Krock B (2017a) Amphidoma languida (Amphidomatacea, Dinophyceae) with a novel azaspiracid toxin profile identified as the cause of molluscan contamination at the Atlantic coast of southern Spain. Harmful Algae 62:113-126. https://doi.org/10. 1016/j.hal.2016.12.001

Tillmann U, Trefault N, Krock B, Parada-Pozo G, De La Iglesia R, Vásquez M (2017b) Identification of Azadinium poporum (Dinophyceae) in the Southeast Pacific: morphology, molecular phylogeny, and azaspiracid profile characterization. J Plankton Res 39:350-367. https://doi.org/10.1093/plankt/fbw099

Tillmann U, Sánchez-Ramires S, Krock B, Bernales-Jiménez A (in revision) A bloom of Azadinium polongum (Dinophyceae) in coastal waters off Peru. In revision, Revista de Biología Marina y Oceanografía

Trainer VL, Moore L, Bill BD, Adams NG, Harrington N, Borchert J, Silva DAM, Eberhard BTL (2013) Diarrhetic shellfish toxins and other lipophilic toxins of human health concern in Washington State. Mar Drugs 11:1815-1835. https://doi.org/10.3390/ md11061815

Turner AD, Goya AB (2015) Occurrence and profiles of lipophilic toxins in shellfish harvested from Argentina. Toxicon 102:32-42. https://doi.org/10.1016/j.toxicon.2015.05.010

Twiner M, Hess P, Doucette GJ (2014) Azaspiracids: toxicology, pharmacology, and risk assessment. In: Botana LM (ed) Seafood and freshwater toxins. CRC Press, Boca Raton, pp 823-855

Utermöhl H (1958) Zur Vervollkommnung der quantitativen Phytoplankton: Methodik. Mitt Int Ver Theor Angew Limnol 9:1-39

Vale P, Bire R, Hess P (2008) Confirmation by LC-MS/MS of azaspiracids in shellfish from the Portuguese north-western coast. Toxicon 51:1449-1456. https://doi.org/10.1016/j.toxicon. 2008.03.022

Yao J, Tan Z, Zhou D, Guo M, Xing L, Yang S (2010) Determination of azaspiracid-1 in shellfishes by liquid chromatography with tandem mass spectrometry. Chin J Chromatogr 28:363-367. https://doi.org/10.3724/SP.J.1123.2010.00363

Yentsch CS, Menzel DW (1963) A method for the determination of phytoplankton chlorophyll and phaeophytin by fluorescence. Deep-Sea Res 10:221-231. https://doi.org/10.1016/00117471(63)90358-9 